CONTRACT AF $33(616)-8438$ PROJECT 7381 : TASK 738103

\title{
POLYETHYLENE TEREPHTHALATE \\ Data Sheets
}

John T. Milek

DS- 105

June 1962
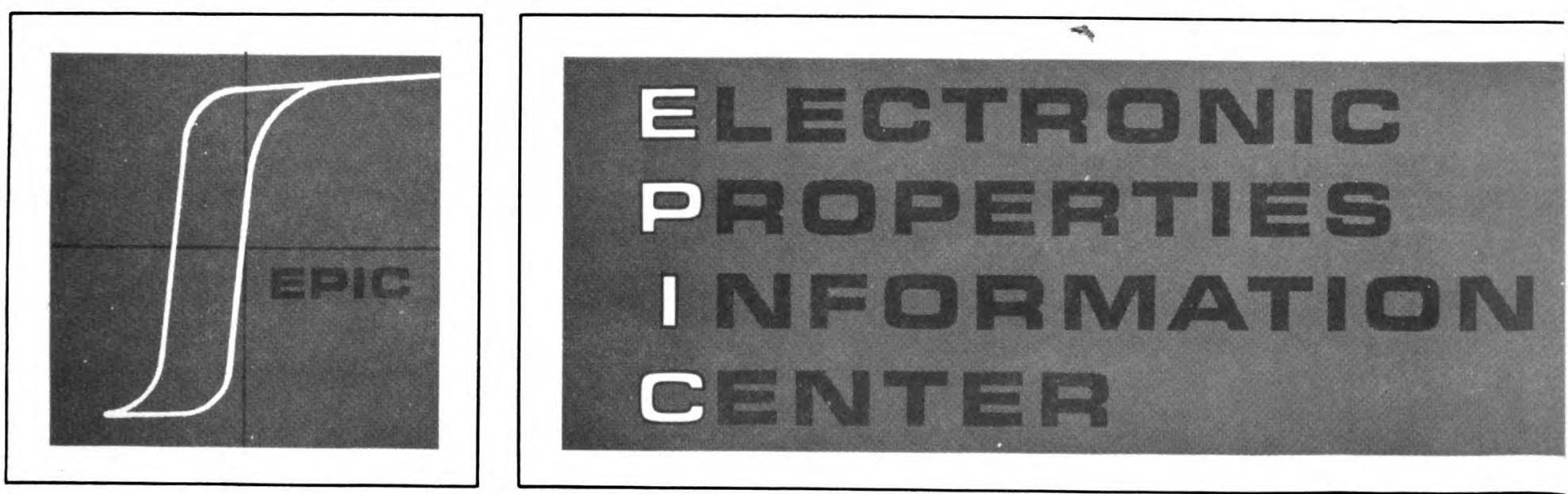

HUGHES

MUGHES AIRCRAFT COMPANY
CULVER CITY. CALIFORNIA 